\title{
High Expression of Pulmonary Proteinase-activated Receptor 2 in Acute and Chronic Lung Injury in Preterm Infants
}

\author{
KATARIINA CEDERQVIST, CAJ HAGLUND, PÄIVI HEIKKILÄ, MORLEY D. HOLLENBERG, \\ RIITTA KARIKOSKI, AND STURE ANDERSSON \\ Hospital for Children and Adolescents [K.C., S.A.], Department of Surgery [C.H.], and Department of \\ Pathology [P.H., R.K.], University of Helsinki, FIN-00029 Helsinki, Finland; Departments of \\ Pharmacology \& Therapeutics and Medicine [M.D.H.], University of Calgary Faculty of Medicine, \\ Calgary AB, Canada T2N $4 N 1$
}

\begin{abstract}
Proteinase-activated receptor $2\left(\mathrm{PAR}_{2}\right)$, a G-protein-coupled receptor activated by serine proteinases such as trypsin, has been suggested to play an important role in inflammatory and fibroproliferative processes. In preterm infants, the development of bronchopulmonary dysplasia (BPD) is characterized by early pulmonary inflammation and subsequent interstitial fibrosis. High pulmonary trypsin-2 has been shown to be associated with the development of BPD. We studied the expression and distribution of $\mathrm{PAR}_{2}$ and trypsin- 2 by immunohistochemistry in autopsy lung specimens of fetuses $(n=10)$, of preterm infants who died of acute or prolonged respiratory distress syndrome (RDS) ( $n=8$ and $n=7$, respectively) or BPD $(n=6)$, and of newborn infants without lung disease $(n=5)$ who served as controls. In prolonged $\mathrm{RDS}$ and $\mathrm{BPD}, \mathrm{PAR}_{2}$ immunoreactivity was significantly higher in bronchial epithelium when compared with infants without pulmonary pathology $(p<0.05$ and $p<0.005$,
\end{abstract}

\section{ABSTRACT}

respectively). In alveolar epithelium, expression of $\mathrm{PAR}_{2}$ was elevated in prolonged RDS when compared with newborn infants without pulmonary pathology $(p<0.05$ ). Moreover, strong expression of $\mathrm{PAR}_{2}$ was detected in myofibroblasts of thickened and fibrotic alveolar walls in prolonged RDS or BPD. Trypsin-2 was co-localized with $\mathrm{PAR}_{2}$ in bronchoalveolar epithelium. These findings suggest that $\mathrm{PAR}_{2}$, possibly activated by trypsin-2, may participate in inflammation and fibroproliferation associated with progression of RDS toward BPD in preterm infants. (Pediatr Res 57: 831-836, 2005)
Abbreviations
BPD, Bronchopulmonary dysplasia
$\mathbf{P A R}_{\mathbf{2}}$, Proteinase-activated receptor 2
RDS, Respiratory distress syndrome

Proteinase-activated receptor $2\left(\mathrm{PAR}_{2}\right)$ is a member of a family of four G-protein-coupled receptors that are activated by proteolytic cleavage of their extracellular N-terminal domain $(1,2)$. The new $\mathrm{N}$-terminus that is exposed by proteolysis binds to and autoactivates the receptor $(3,4)$. To date, four PARs have been identified. Of them $\mathrm{PAR}_{1}, \mathrm{PAR}_{3}$, and $\mathrm{PAR}_{4}$ are targeted by thrombin, whereas $\mathrm{PAR}_{2}$ is activated by trypsin and tryptase. $\mathrm{PAR}_{2}$ is expressed in tissues such as intestine, pancreas, kidney, heart, vascular endothelium and lung (4-6). In the human lung, $\mathrm{PAR}_{2}$ is expressed in airway epithelium and

Received March 15, 2004; accepted September 30, 2004.

Correspondence: Katariina Cederqvist, M.D., Hospital for Children and Adolescents, Research laboratory, Biomedicum Helsinki, P.O. Box 700, FIN-00290 Helsinki, Finland; e-mail: katariina.cederqvist@helsinki.fi

Supported by grants from the Foundation for the Pediatric Research, Finska Läkaresällskapet, the Sigrid Jusélius Foundation, the Helsinki University Central Hospital Research Fund and the Canadian Institutes of Health Research (MDH).

DOI: 10.1203/01.PDR.0000161416.63314.70 smooth muscle, in fibroblasts, and in vascular endothelium and smooth muscle (6-8). Several studies indicate that activation of $\mathrm{PAR}_{2}$ may be important in inflammation, tissue remodeling, and fibroproliferation (8-13). In the airways, both pro- and anti-inflammatory roles for $\mathrm{PAR}_{2}$ have been suggested $(7,10,12)$.

In very low birth weight infants bronchopulmonary dysplasia (BPD) is a common chronic lung disease with multifactorial etiology (14-17). Several studies have shown that inflammation plays an important role in the pathogenesis of BPD (17-20). In preterm infants with respiratory distress syndrome (RDS), during the first postnatal days an inflammatory reaction takes place in the lungs characterized by accumulation and activation of inflammatory cells and release of inflammatory mediators in the airways and interstitium. Infants who subsequently develop BPD have a more pronounced and persistent pulmonary inflammation when compared with infants who recover from RDS $(18,19)$. Slowly resolving inflammation and 
excessive reparative processes lead to pulmonary fibroproliferation and abnormal lung development, but the mechanisms remain to be characterized.

We have previously demonstrated that in preterm infants, the development of BPD is associated with high pulmonary levels of trypsin-2 during the early postnatal period (21). We hypothesized that activation of $\mathrm{PAR}_{2}$ could be an important mechanism through which trypsin-2 causes damage in the preterm lung. Therefore, we studied the expression and potential co-localization of $\mathrm{PAR}_{2}$ and trypsin- 2 by immunohistochemistry in autopsy specimens of fetuses, of preterm infants with RDS or BPD, and of newborn infants without lung disorder.

\section{METHODS}

Patients. A total of 10 fetuses aborted because of major extrapulmonary anomalies between 1997 and 2000, and 26 infants who died between 1992 and 1998 in the University Central Hospital, Helsinki, were studied. The preterm infants who died of acute (age at death $0-2 \mathrm{~d} ; n=8$ ) or prolonged RDS (age at death $8-16 \mathrm{~d} ; n=7$ ) were mechanically ventilated and received treatment with surfactant, and the autopsies showed hyaline membranes. BPD was defined as the need for supplemental oxygen at the age of 36 gestational weeks, in association with chest radiographic findings typical for BPD (22). As controls, newborn infants $(n=5)$ who died within $1 \mathrm{~d}$ after delivery for different reasons without lung disorders were included. Of the newborn controls, 3 received no mechanical ventilation or supplemental oxygen (gestational ages 22-22.7 wk). Mechanical ventilation and supplemental oxygen was given to 2 infants (gestational ages 26.1 and $33.0 \mathrm{wk}$ ) for 2 and $20 \mathrm{~h}$, respectively. None of the fetuses or infants presented with any lung anomalies or pneumonia at the time of death. The clinical information on the fetuses is given in Table 1 and on the infants in Table 2. Autopsies were performed within $3 \mathrm{~d}$ after death. The lung samples were fixed in $10 \%$ neutral buffered formalin, embedded in paraffin, and stored at room temperature. Fourmicrometer sections were stained with hematoxylin-eosin. After evaluating the whole material, one representative tissue block from each case was selected for immunohistochemical studies.

The study was done with the approval of the Ethics Committee of the Hospital for Children and Adolescents, University Central Hospital, Helsinki.

Immunohistochemistry. $\mathrm{PAR}_{2}$ immunoreactivity was visualized with polyclonal anti-PAR $\mathrm{P}_{2}$ antibody $\mathrm{B} 5$ raised in rabbits against a peptide fragment of rat PAR $_{2}\left({ }^{30}\right.$ GPNSKGR $\downarrow$ SLIGRLDT ${ }^{45} \mathrm{P}-Y G G C$, where “ $\downarrow$ ” designates the $\mathrm{PAR}_{2}$ trypsin cleavage/activation site, with the sequence $Y G G C$ added for derivitization) and cross-reacts with both rat and human $\operatorname{PAR}_{2}(23,24)$. Trypsin-2 immunoreactivity was visualized with monoclonal anti-trypsin-2 antibody $8 \mathrm{~F} 7(25)$.

Four-micrometer sections were deparaffinized, rehydrated, and microwaved. The sections were then treated with $0.5 \%$ hydrogen peroxide in methanol for $30 \mathrm{~min}$ and blocked with either normal goat serum $\left(\mathrm{PAR}_{2}\right)$ or normal horse serum (trypsin-2) (both 1:20) for 15 min. Primary antibody to $\mathrm{PAR}_{2}$ (diluted 1:1000) or to trypsin-2 (diluted 1:1000) was added, and the sections were incubated overnight at room temperature. For $\mathrm{PAR}_{2}$, negative controls were performed by preabsorbing the antibody with the nonconjugated immunogenic peptide present at a concentration of approximately $20 \mu \mathrm{g} / \mathrm{mL}$ in the antibody (1:1000)-containing buffer and incubating $3 \mathrm{~h}$ at room tempera- ture before application to the tissue. Additional negative controls were performed by substituting the primary antibody with neutral isotonic PBS (PBS). For trypsin-2, sections treated with nonimmune mouse serum or PBS served as negative controls. Bound antibody was visualized by the avidin-biotin complex immunoperoxidase technique (ABC) (Elite ABC Kit, Vectastain, Vector Laboratories, Burlingame, CA) following the manufacturer's instructions. The sections were incubated with the biotinylated second layer antibody and the peroxidase-labeled avidin-biotin complex for $30 \mathrm{~min}$ each. Peroxidase activity was developed with 3-amino-9-ethyl-carbazole (Sigma Chemical Co., A-5754), and finally the sections were stained with hematoxylin.

To confirm the presence of $\mathrm{PAR}_{2}$ on macrophages or myofibroblasts, consecutive sections were immunostained with an antibody against the specific macrophage marker CD-163 (diluted 1:100) (Novocastra, Newcastle upon Tyne, UK) or $\alpha$-smooth muscle actin (diluted1:5000) (Biomakor, Rehovot, Israel).

Scoring of PAR Immunoreactivity and Statistical Analysis. The analysis of $\mathrm{PAR}_{2}$ immunoreactivity was performed independently by two investigators (K.C. and P.H.) in a blinded fashion. In each case, the entire section of lung tissue (approximately $1-2 \mathrm{~cm}^{2}$ ) was evaluated. The level of $\mathrm{PAR}_{2}$ immunoreactivity was scored in a semiquantitative manner according to the following method: absent $=0$, low $=1$, moderate $=2$, strong $=3$, or very strong $=4$. Separate scores were given for bronchial and bronchiolar epithelium, alveolar epithelium, bronchial and vascular smooth muscle cells, and vascular endothelium. Data for the level of $\mathrm{PAR}_{2}$ immunoreactivity are given as medians and interquartiles. Comparisons between groups were performed with the nonparametric multiple comparison Kruskal-Wallis test (StatView 5.0.1, Abacus Concepts Inc., Berkeley, CA). The Dunn's test was used for the post hoc comparisons. $\mathrm{P}$ values less than 0.05 were considered statistically significant.

\section{RESULTS}

Immunohistochemistry for $\boldsymbol{P A R}$. In all fetuses and infants, positive immunostaining for $\mathrm{PAR}_{2}$ was detected in bronchial and bronchiolar epithelium, and in alveolar epithelium. Positive immunostaining for $\mathrm{PAR}_{2}$ was also found in bronchial and vascular smooth muscle and in vascular endothelium. Preabsorption of $\mathrm{PAR}_{2}$ with the nonconjugated immunogenic peptide eliminated the staining (data not shown).

Fetuses. $\mathrm{PAR}_{2}$ immunoreactivity in bronchial and bronchiolar epithelium was low or moderate; however, in one fetus with gestational age $14 \mathrm{wk}$, the immunoreactivity was strong (Figs. $1 A$ and $2 A$ ). In cuboidal type-II-like pneumocytes lining the prospective pulmonary acini the immunoreactivity was moderate or strong, and it had a tendency to be stronger when compared with newborn infants without lung pathology although the difference did not reach statistical significance $(p=$ $0.06)$ (Figs. $1 B$ and $2 B$ ). The vascular endothelium and the bronchial and vascular walls were negative or showed only low immunoreactivity for PAR-2 (Figs. $1 C-E, 2 A$ ).

Newborn controls. In newborn infants without lung pathology, the expression of $\mathrm{PAR}_{2}$ in the studied cell types was predominantly low (Figs. 1 and $3 A$ ).

Table 1. Clinical data of fetuses

\begin{tabular}{|c|c|c|c|c|}
\hline Fetus & $\begin{array}{c}\text { Gestational age } \\
\text { (wk) }\end{array}$ & $\begin{array}{l}\text { Weight } \\
\text { (g) }\end{array}$ & $\begin{array}{l}\text { Gender } \\
(\mathrm{M} / \mathrm{F})\end{array}$ & Diagnosis \\
\hline 1 & 14 & 30 & Unknown & Meningomyelocele \\
\hline 2 & 15 & 60 & M & Nonketotic hyperglycinemia \\
\hline 4 & 18 & 110 & M & Anencephaly \\
\hline 5 & 18 & 160 & $\mathrm{M}$ & Meningomyelocele \\
\hline 6 & 18 & 200 & M & Hypoplastic left heart syndrome \\
\hline 9 & 21 & 380 & M & Meningomyelocele \\
\hline 10 & 22 & 510 & M & Hydrocephalus \\
\hline
\end{tabular}


Table 2. Clinical data of newborn controls and preterm infants with RDS or BPD

\begin{tabular}{|c|c|c|c|c|c|}
\hline Patient & $\begin{array}{c}\text { Gestational age } \\
\text { (wk) }\end{array}$ & $\begin{array}{l}\text { Birth weight } \\
\text { (g) }\end{array}$ & $\begin{array}{l}\text { Age at } \\
\text { death }\end{array}$ & $\begin{array}{l}\text { Gender } \\
(\mathrm{M} / \mathrm{F})\end{array}$ & Cause of death \\
\hline 1 & 22.4 & 510 & $15 \mathrm{~min}$ & $\mathrm{~F}$ & Fetofetal transfusion \\
\hline 2 & 22.7 & 340 & $16 \mathrm{~min}$ & M & Rupture of fetal membranes \\
\hline 4 & 22.0 & 540 & $3 \mathrm{hr}$ & M & Spontaneous abortion \\
\hline 5 & 33.0 & 2230 & $1 \mathrm{~d}$ & M & Acute asphyxia \\
\hline 6 & 29.7 & 1525 & $12 \mathrm{hr}$ & M & RDS, fetofetal transfusion \\
\hline 9 & 27.7 & 840 & $1 \mathrm{~d}$ & $\mathrm{~F}$ & RDS \\
\hline 10 & 25.7 & 500 & $2 d$ & M & RDS \\
\hline 11 & 25.0 & 305 & $2 \mathrm{~d}$ & $\mathrm{~F}$ & RDS \\
\hline 12 & 23.9 & 570 & $2 \mathrm{~d}$ & M & RDS \\
\hline 13 & 24.0 & 520 & $2 \mathrm{~d}$ & $\mathrm{~F}$ & RDS \\
\hline 14 & 25.7 & 675 & $8 \mathrm{~d}$ & M & Prolonged RDS \\
\hline 19 & 26.4 & 925 & $13 \mathrm{~d}$ & M & Prolonged RDS \\
\hline 20 & 26.4 & 670 & $16 \mathrm{~d}$ & $\mathrm{~F}$ & Prolonged RDS \\
\hline 21 & 26.4 & 700 & $75 \mathrm{~d}$ & M & BPD, cystic PVL \\
\hline 22 & 28.9 & 765 & $82 \mathrm{~d}$ & M & BPD \\
\hline 23 & 26.0 & 1250 & $121 \mathrm{~d}$ & M & BPD, hydrocephalus \\
\hline 24 & 29.0 & 1070 & $175 \mathrm{~d}$ & M & BPD, cor pulmonale \\
\hline 25 & 28.9 & 1160 & $180 \mathrm{~d}$ & M & BPD, hydrocephalus \\
\hline 26 & 31.3 & 750 & $306 \mathrm{~d}$ & M & BPD \\
\hline
\end{tabular}

PVL, periventricular leukomalacia.

$\boldsymbol{R D S}$. In preterm infants who died of acute RDS at the age of 0-2 d, immunoreactivity for $\mathrm{PAR}_{2}$ was strongest in bronchial and bronchiolar epithelium (Fig. 1). The immunoreactivity in alveolar epithelium was low in 4 of the 8 preterm infants (Figs. $1 B$ and $3 B$ ). In the studied cell types, no significant difference was detected in the level of PAR-2 immunoreactivity between preterm infants who died of acute RDS and newborn infants without lung pathology.

Prolonged RDS. In preterm infants who died of prolonged RDS at the age of 8-16 d, the expression of $\mathrm{PAR}_{2}$ was strongest in bronchial and bronchiolar epithelium and in alveolar epithelium (Figs. 1, 3C, 3D). When compared with newborn controls, $\mathrm{PAR}_{2}$ immunoreactivity was significantly higher in bronchial and bronchiolar epithelium, in alveolar epithelium, and in bronchial and vascular smooth muscle (Fig. 1). In addition, expression of $\mathrm{PAR}_{2}$ in vascular endothelium tended to be higher when compared with newborn controls $(p=0.07)$. In all infants who died of prolonged RDS, $\mathrm{PAR}_{2}$ was also detected in spindle-shaped cells of thickened alveolar walls and fibrotic foci (Fig. 3C). These cells were strongly positive in immunohistochemical staining for $\alpha$-smooth muscle actin thus obviously representing lung myofibroblasts (26).

$\boldsymbol{B P D}$. In preterm infants who died of $\mathrm{BPD}, \mathrm{PAR}_{2}$ immunoreactivity was strongest in bronchial and bronchiolar epithelium (Fig. 1). When compared with newborn infants without lung pathology, $\mathrm{PAR}_{2}$ immunoreactivity was significantly higher in bronchial and bronchiolar epithelium and in bronchial smooth muscle (Fig. 1). As in infants who died of prolonged RDS, in all infants with BPD strong expression of $\mathrm{PAR}_{2}$ was detected in $\alpha$-smooth muscle actin-positive myofibroblasts of thickened and fibrotic alveolar walls (Figs. $3 E$ and $3 F$ ). In addition, $\mathrm{PAR}_{2}$ was expressed in alveolar macrophages (Fig. $3 E$ ) that were positive for CD-163 (data not shown).

Immunohistochemistry for trypsin-2. In accordance with our previous findings, trypsin-2 was expressed predominantly in the bronchial and bronchiolar epithelium (21). Vascular endothelium was negative except in 2 preterm infants who died of prolonged RDS. No trypsin-2 immunoreactivity was detected in bronchial or vascular smooth muscle cells. In fetuses, faint expression of trypsin-2 was detected in bronchial and bronchiolar epithelium in 5 samples whereas 5 samples were totally negative. Similarly, in newborn infants without lung pathology, bronchial and bronchiolar epithelium was weakly positive in 3 of the 5 infants. In preterm infants who died of RDS, bronchial and bronchiolar epithelium and hyaline membranes showed low trypsin-2 immunoreactivity in 4 infants. In contrast, in preterm infants who died of prolonged RDS at the age of $8-16 \mathrm{~d}$, the expression of trypsin-2 was predominantly strong in bronchial and bronchiolar epithelium and in type-II-like pneumocytes lining alveolar walls; in these structures trypsin-2 co-localized with $\mathrm{PAR}_{2}$ (Figs. $4 A$ and $4 B$ ). In addition, in 2 of the preterm infants who died of prolonged RDS, trypsin-2 immunoreactivity was also detected in vascular endothelium; in these infants vascular endothelial cells showed strong $\mathrm{PAR}_{2}$ immunoreactivity (Figs. $4 C$ and $4 D$ ). In preterm infants who died of BPD, trypsin-2 immunoreactivity co-localized with $\mathrm{PAR}_{2}$ immunoreactivity in bronchial and bronchiolar epithelium and varied from low to strong, while alveolar epithelium was predominantly negative (Figs. $4 E$ and $4 F$ ). 

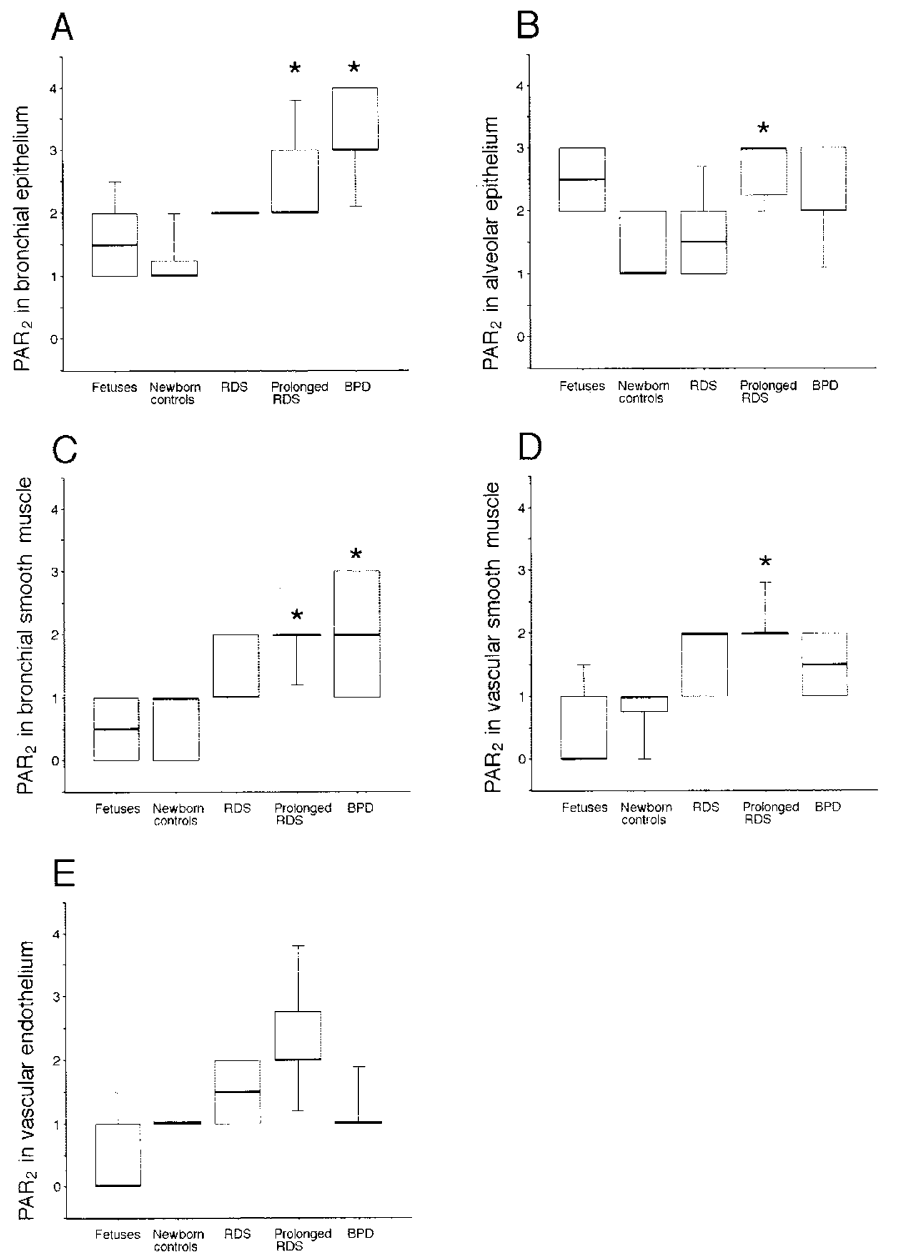

Figure 1. Box plot of semiquantitative analysis of PAR-2 immunoreactivity in different types of pulmonary cells in fetuses, in newborn infants without lung disorders (newborn controls), and in preterm infants who died of RDS or BPD. (A) Bronchial and bronchiolar epithelium, $(B)$ alveolar epithelium, $(C)$ bronchial smooth muscle, $(D)$ vascular smooth muscle, and $(E)$ vascular endothelium. Semiquantitative scoring of $\mathrm{PAR}_{2}$ immunoreactivity was assessed as follows: absent $=0$, low $=1$, moderate $=2$, strong $=3$, or very strong $=4$. Box denotes the 25th, 50th, and 75th percentiles while whiskers represent the 10th and 90th percentiles. $* p<0.05 v s$ newborn controls.
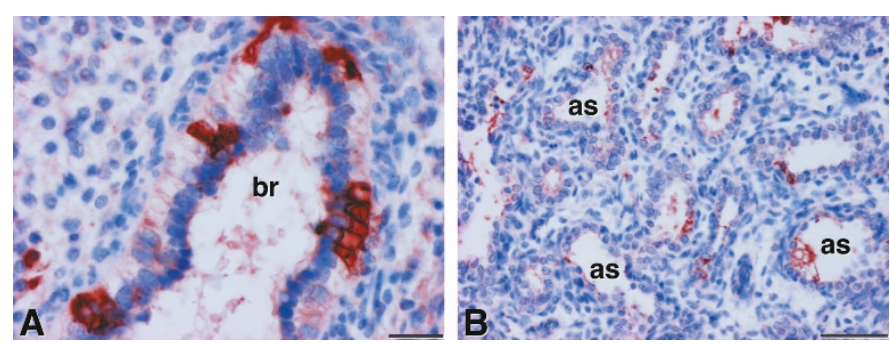

Figure 2. Immunohistochemical localization of $\mathrm{PAR}_{2}$ in fetal lung. (A) $\mathrm{PAR}_{2}$ immunoreactivity in bronchiolar epithelium (gestational age $14 \mathrm{wk}$ ). $\mathrm{Bar}=20$ $\mu \mathrm{m}(B) \mathrm{PAR}_{2}$ immunoreactivity in cuboidal type-II-like pneumocytes (gestational age $21 \mathrm{wk})$. Bar $=50 \mu \mathrm{m}$. as: airspace, br: bronchiole.

\section{DISCUSSION}

In the present study we demonstrate that $\mathrm{PAR}_{2}$ is highly expressed in airway epithelium of preterm infants who died of prolonged RDS or of BPD, and that the expression is significantly stronger in comparison with newborn infants without

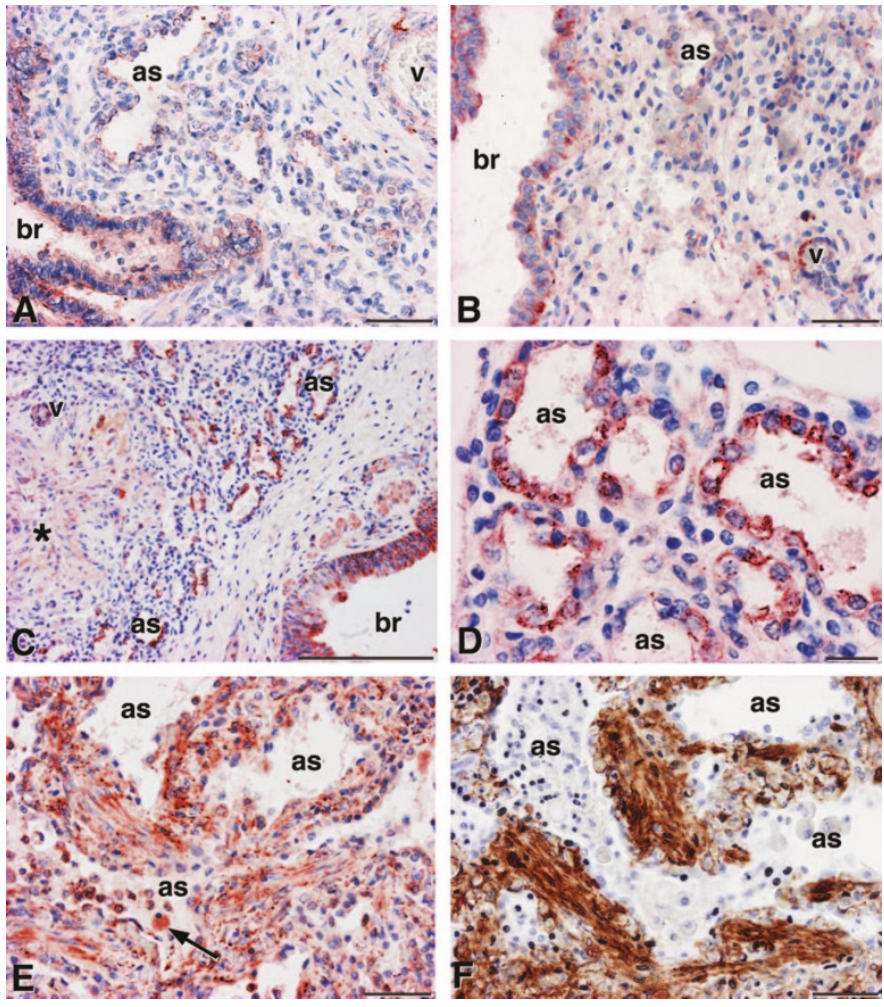

Figure 3. Immunohistochemical localization of $\mathrm{PAR}_{2}$ in lungs of infants. $(A)$ Newborn infant who died of placental ablation (gestational age $26.1 \mathrm{wk}$, age at death $2 \mathrm{~h}$ ). No histologic signs of RDS in postmortem examination. Bar $=50$ $\mu \mathrm{m}(B)$ Preterm infant who died of RDS (gestational age $25.0 \mathrm{wk}$, age at death $2 \mathrm{~d}$ ). Bar $=50 \mu \mathrm{m}(C)$ Preterm infant who died of prolonged RDS (gestational age 26.4 wk, age at death $13 \mathrm{~d})$. Bar $=200 \mu \mathrm{m}(D)$ High-power field of the same patient as in C. Bar $=20 \mu \mathrm{m}$. $(E)$ Preterm infant who died of BPD (gestational age $29 \mathrm{wk}$, age at death $175 \mathrm{~d}$ ). Bar $=50 \mu \mathrm{m}(F)$ Immunohistochemical staining for $\alpha$-smooth muscle actin of the same patient as in E. Bar $=50 \mu \mathrm{m}$. Asterisk: fibrotic focus, arrow: alveolar macrophage, as: airspace, br: bronchiole, v: vessel.

lung pathology. The level of $\mathrm{PAR}_{2}$ expression also showed a trend to increase with progression of RDS toward BPD. Moreover, in preterm infants with lung injury we found that trypsin-2, a potential activator of $\mathrm{PAR}_{2}$, is co-localized with $\mathrm{PAR}_{2}$ in the airway epithelium. $\mathrm{PAR}_{2}$ expression was also evident in bronchial and vascular smooth muscle, and in vascular endothelium in lungs of preterm infants with RDS or BPD and of term infants without lung pathology. This localization in infants is in accordance with earlier studies showing $\mathrm{PAR}_{2}$ expression in adult human lung tissue $(6,7,27)$.

Several studies done in vitro and in experimental animals have suggested that $\mathrm{PAR}_{2}$ is involved in inflammation and tissue remodeling $(9,10,12,13)$. Exposure to proinflammatory agents up-regulates $\mathrm{PAR}_{2}$ in vascular endothelium and its activation induces vascular permeability and infiltration of neutrophils $(9,28)$. In respiratory epithelium, activation of $\mathrm{PAR}_{2}$ stimulates the release of inflammatory mediators such as IL-6, IL-8, and matrix metalloproteinase-9, suggesting an important role for $\mathrm{PAR}_{2}$ in inflammation and tissue remodeling in the lung $(10,12)$. In preterm infants with respiratory distress, the development of BPD is characterized by persistent inflammatory pulmonary reaction associated with epithelial cell dam- 


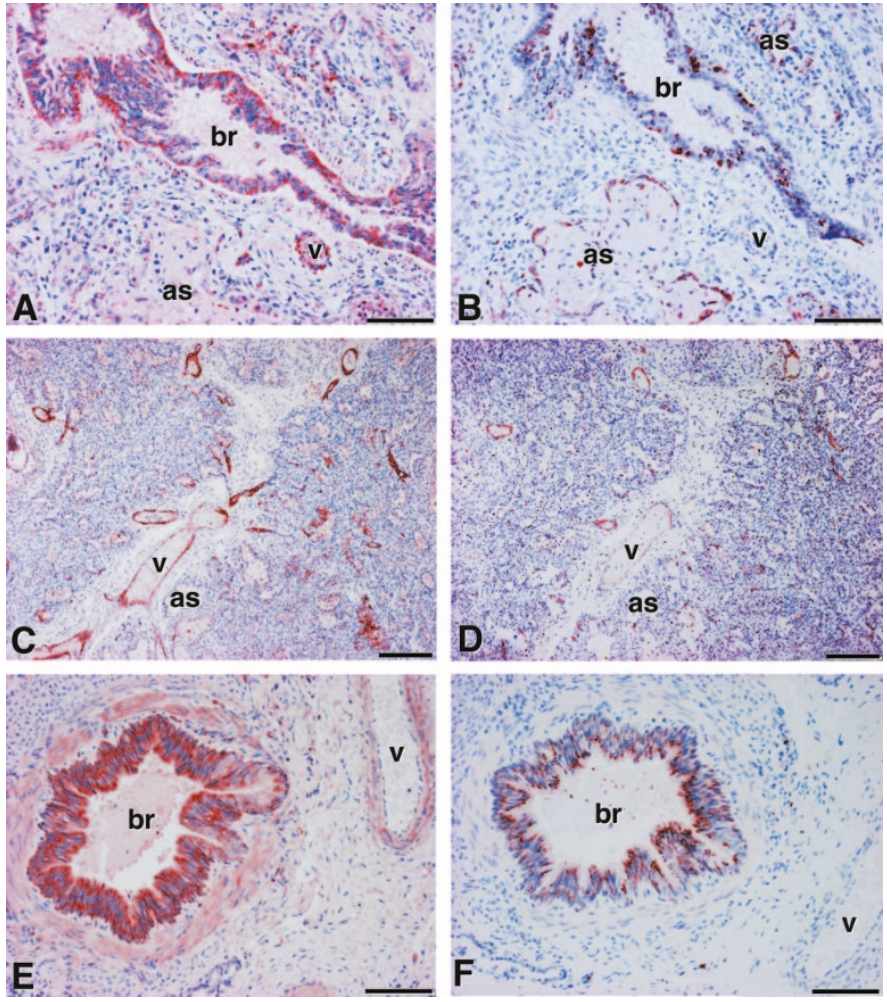

Figure 4. Immunohistochemical localization of $\mathrm{PAR}_{2}$ and trypsin-2 in lungs of preterm infants. (A) $\mathrm{PAR}_{2}$ expression in a preterm infant who died of prolonged RDS (gestational age $29.9 \mathrm{wk}$, age at death $8 \mathrm{~d}$ ). Bar $=100 \mu \mathrm{m}(B)$ Trypsin-2 expression in the same patient as in A. Bar $=100 \mu \mathrm{m}(C) \mathrm{PAR}_{2}$ expression in a preterm infant who died of prolonged RDS (gestational age 24.6 wk, age at death $11 \mathrm{~d})$. Bar $=200 \mu \mathrm{m}(D)$ Trypsin-2 expression in the same patient as in C. Bar $=200 \mu \mathrm{m}(E) \mathrm{PAR}_{2}$ expression in a preterm infant who died of BPD (gestational age $28.9 \mathrm{wk}$, age at death $82 \mathrm{~d}$ ). Bar $=100 \mu \mathrm{m}$ (F) Trypsin-2 expression in the same patient as in E. Bar $=100 \mu \mathrm{m}$. as: airspace, br: bronchiole, v: vessel.

age and increased alveocapillary permeability (18-20). During the first 2 wk of life, broncho-alveolar secretions show higher numbers of inflammatory cells and increased levels of proinflammatory agents such as TNF- $\alpha$, IL-6, IL-8, and various proteases in preterm infants who subsequently develop BPD in comparison with those who recover from RDS $(18-21,29,30)$. In addition to alveolar macrophages, vascular endothelium and respiratory epithelium play an important role in the production of the pro-inflammatory cytokines $(29,31,32)$. In this study we showed up-regulation of $\mathrm{PAR}_{2}$ in the bronchoalveolar epithelium of preterm infants with prolonged RDS, and in the bronchial epithelium of preterm infants with BPD. In addition, in preterm infants with prolonged RDS, the expression of $\mathrm{PAR}_{2}$ appeared to be increased in vascular endothelium. These findings suggest that up-regulation of $\mathrm{PAR}_{2}$ in lungs of preterm infants is associated with the development of chronic inflammatory pulmonary disease of preterm infants. This pulmonary up-regulation is in accordance with an earlier report of increased expression of $\mathrm{PAR}_{2}$ in bronchial epithelium in asthma in adult patients (11).

The endogenous activator(s) of $\mathrm{PAR}_{2}$ in the lung remains largely to be determined. In normal adult lung tissue, immunoreactivity for trypsin(ogen) was co-localized with $\mathrm{PAR}_{2}$ in the airway epithelium (7). Therefore, it has been suggested that trypsin, tightly regulated by protease inhibitors such as $\alpha_{1}$ antitrypsin, may be a physiologic activator of epithelial $\mathrm{PAR}_{2}$ in the lungs, and that epithelial $\mathrm{PAR}_{2}$ is involved in cytoprotection rather than inflammation $(7,33)$. Like pancreatic trypsin, its isoenzyme trypsin- 2 is a potent $\mathrm{PAR}_{2}$ activator (34). We have previously shown that trypsin- 2 is strongly expressed in lungs of preterm infants with respiratory distress, and that during the first 2 postnatal weeks, high levels of pulmonary trypsinogen-2 are associated with subsequent development of BPD (21). In the present study we demonstrated that in preterm infants who died of prolonged RDS or BPD, trypsin-2 is co-localized with $\mathrm{PAR}_{2}$ in bronchial and alveolar epithelium. Furthermore, expression of trypsin-2 was also detected in the vascular endothelium of those preterm infants with prolonged RDS who presented with strong endothelial $\mathrm{PAR}_{2}$ expression. We hypothesize that activation of $\mathrm{PAR}_{2}$ in the lungs of preterm infants by high levels of trypsin- 2 during the early postnatal period may play a role in persistent inflammatory pulmonary reaction associated with the development of BPD. This hypothesis is also supported by earlier studies showing deficiency in pulmonary $\alpha_{1}$-antitrypsin in preterm infants with RDS $(35,36)$.

To be capable of activating $\mathrm{PAR}_{2}$ in the lung, trypsinogen must be processed by specific enzymes. At present, it is unclear how trypsinogen is activated outside the intestine where it is activated by enteropeptidase. In vitro, it has been shown that incubation of activated leukocytes with trypsinogen can result in a conversion of trypsinogen to trypsin (37). This leukocytemediated mechanism could be one by which trypsinogen may be activated in the lungs of preterm infants with respiratory distress. Further studies on the mechanism of trypsin activation are important, since the trypsinogen to trypsin activators themselves might be a therapeutic target.

Both tryptase and trypsin appear capable of inducing lung fibroblast proliferation via activation of $\mathrm{PAR}_{2}$ (8). Myofibroblasts are derived from activated fibroblasts, and play an important role in tissue remodeling following acute lung injury $(26,38)$. In preterm infants with acute lung injury, myofibroblasts have been shown to increase in number and form bundles encircling terminal air spaces during the early postnatal period (26). Interestingly, in preterm infants who died of prolonged RDS or BPD, we detected strong expression of $\mathrm{PAR}_{2}$ in $\alpha$-smooth muscle actin-positive myofibroblasts of thickened and fibrotic alveolar walls. This observation suggests that $\mathrm{PAR}_{2}$ might be involved in fibroproliferation associated with the development of BPD.

We detected predominantly low expression of $\mathrm{PAR}_{2}$ in the normal fetal lung. The bronchial and the vascular walls and vascular endothelium were almost negative; in contrast, in type-II-like pneumocytes lining the prospective pulmonary acini $\mathrm{PAR}_{2}$ immunoreactivity was moderate or strong. All of the fetuses were aborted because of a clinical suspicion of a major malformation in fetal ultrasound examination. None of the mothers had clinical symptoms of chorioaminonitis, and no signs of infection could be detected in histologic examination of fetal tissues and placenta. Therefore, an inflammatory process in the fetal lungs is an unlikely explanation for marked 
$\mathrm{PAR}_{2}$ immunoreactivity in the cuboidal type II-like epithelial cells. Whether $\mathrm{PAR}_{2}$ expression in the fetal lung is affected by the prostaglandin used to induce the abortion, or possibly by hypoxia associated with the induced abortion, cannot be ruled out in this study. The possible role(s) of $\mathrm{PAR}_{2}$ in the developing fetal lung remains a topic of considerable interest for future studies.

In conclusion, $\mathrm{PAR}_{2}$ and its potential activator trypsin- 2 are co-localized in the lungs of preterm infants with prolonged RDS or BPD. We suggest that activation of $\mathrm{PAR}_{2}$ in the preterm lung by high levels of trypsin-2 may play a role in pulmonary inflammation and fibroproliferation associated with the development of BPD. Overall, our data point to both trypsin- 2 and $\mathrm{PAR}_{2}$ as potential therapeutic targets in the setting of RDS and BPD in preterm infants.

Acknowledgments. The authors thank Prof. Seppo Sarna, $\mathrm{Ph} . \mathrm{D}$., for his help with statistical analysis of the data, and Elina Laitinen and Päivi Peltokangas for excellent technical assistance.

\section{REFERENCES}

1. Dery O, Corvera CU, Steinhoff M, Bunnett NW 1998 Proteinase-activated receptors: novel mechanisms of signaling by serine proteases. Am J Physiol 274:C1429-C1452

2. Hollenberg MD, Compton SJ 2002 International Union of Pharmacology. XXVIII Proteinase-activated receptors. Pharmacol Rev 54:203-217

3. Vu TK, Hung DT, Wheaton VI, Coughlin SR 1991 Molecular cloning of a functional thrombin receptor reveals a novel proteolytic mechanism of receptor activation. Cell 64:1057-1068

4. Nystedt S, Emilsson K, Wahlestedt C, Sundelin J 1994 Molecular cloning of a potential proteinase activated receptor. Proc Natl Acad Sci USA 91:9208-9212

5. Böhm SK, Kong W, Bromme D, Smeekens SP, Anderson DC, Connolly A, Kahn M, Nelken NA, Coughlin SR, Payan DG, Bunnett NW 1996 Molecular cloning, expression and potential functions of the human proteinase-activated receptor-2. Biochem $\mathrm{J}$ 314:1009-1016

6. D'Andrea MR, Derian CK, Leturcq D, Baker SM, Brunmark A, Ling P, Darrow AL Santulli RJ, Brass LF, Andrade-Gordon P 1998 Characterization of protease-activated receptor-2 immunoreactivity in normal human tissues. J Histochem Cytochem 46:157-164

7. Cocks TM, Fong B, Chow JM, Anderson GP, Frauman AG, Goldie RG, Henry PJ, Carr MJ, Hamilton JR, Moffatt JD 1999 A protective role for protease-activated receptors in the airways. Nature 398:156-160

8. Akers IA, Parsons M, Hill MR, Hollenberg MD, Sanjar S, Laurent GJ, McAnulty RJ 2000 Mast cell tryptase stimulates human lung fibroblast proliferation via proteaseactivated receptor-2. Am J Physiol Lung Cell Mol Physiol 278:L193-L201

9. Vergnolle N 1999 Proteinase-activated receptor-2-activating peptides induce leukocyte rolling, adhesion, and extravasation in vivo. J Immunol 163:5064-5069

10. Vliagoftis H, Schwingshackl A, Milne CD, Duszyk M, Hollenberg MD, Wallace JL, Befus AD, Moqbel R 2000 Proteinase-activated receptor-2-mediated matrix metalloproteinase-9 release from airway epithelial cells. J Allergy Clin Immunol 106:537545

11. Knight DA, Lim S, Scaffidi AK, Roche N, Chung KF, Stewart GA, Thompson PJ 2001 Protease-activated receptors in human airways: upregulation of PAR-2 in respiratory epithelium from patients with asthma. J Allergy Clin Immunol 108:797803

12. Asokananthan N, Graham PT, Fink J, Knight DA, Bakker AJ, McWilliam AS, Thompson PJ, Stewart GA 2002 Activation of protease-activated receptor (PAR)-1, PAR-2, and PAR-4 stimulates IL-6, IL-8, and prostaglandin E2 release from human respiratory epithelial cells. J Immunol 168:3577-3585

13. Cenac N, Coelho AM, Nguyen C, Compton S, Andrade-Gordon P, MacNaughton WK, Wallace JL, Hollenberg MD, Bunnett NW, Garcia-Villar R, Bueno L, Vergnolle N 2002 Induction of intestinal inflammation in mouse by activation of proteinaseactivated receptor-2. Am J Pathol 161:1903-1915
14. Saugstad OD 1997 Bronchopulmonary dysplasia and oxidative stress: are we closer to an understanding of the pathogenesis of BPD? Acta Paediatr 86:1277-1282

15. Stevenson DK, Wright LL, Lemons JA, Oh W, Korones SB, Papile LA, Bauer CR, Stoll BJ, Tyson JE, Shankaran S, Fanaroff AA, Donovan EF, Ehrenkranz RA, Verter J 1998 Very low birth weight outcomes of the National Institute of Child Health and Human Development Neonatal Research Network, January 1993 through December 1994. Am J Obstet Gynecol 179:1632-1639

16. Jobe AJ 1999 The new BPD: an arrest of lung development. Pediatr Res 46:641-643

17. Speer CP 1999 Inflammatory mechanisms in neonatal chronic lung disease. Eur J Pediatr 158 Suppl 1:S18-S22

18. Merritt TA, Cochrane CG, Holcomb K, Bohl B, Hallman M, Strayer D, Edwards DK 3rd, Gluck L 1983 Elastase and alpha 1-proteinase inhibitor activity in tracheal aspirates during respiratory distress syndrome. Role of inflammation in the pathogenesis of bronchopulmonary dysplasia. J Clin Invest 72:656-666

19. Groneck P, Gotze-Speer B, Oppermann M, Eiffert H, Speer CP 1994 Association of pulmonary inflammation and increased microvascular permeability during the development of bronchopulmonary dysplasia: a sequential analysis of inflammatory mediators in respiratory fluids of high-risk preterm neonates. Pediatrics 93:712-718

20. Watterberg KL, Demers LM, Scott SM, Murphy S 1996 Chorioamnionitis and early lung inflammation in infants in whom bronchopulmonary dysplasia develops. Pediatrics 97:210-215

21. Cederqvist K, Haglund C, Heikkila P, Sorsa T, Tervahartiala T, Stenman UH, Andersson S 2003 Pulmonary trypsin-2 in the development of bronchopulmonary dysplasia in preterm infants. Pediatrics 112:570-577

22. Shennan AT, Dunn MS, Ohlsson A, Lennox K, Hoskins EM 1988 Abnormal pulmonary outcomes in premature infants: prediction from oxygen requirement in the neonatal period. Pediatrics 82:527-532

23. Kong W, McConalogue K, Khitin LM, Hollenberg MD, Payan DG, Bohm SK, Bunnett NW 1997 Luminal trypsin may regulate enterocytes through proteinaseactivated receptor 2. Proc Natl Acad Sci USA 94:8884-8889

24. Al-Ani B, Saifeddine M, Kawabata A, Renaux B, Mokashi S, Hollenberg MD 1999 Proteinase-activated receptor $2(\operatorname{PAR}(2))$ : development of a ligand-binding assay correlating with activation of $\operatorname{PAR}(2)$ by $\operatorname{PAR}(1)$ - and PAR(2)-derived peptide ligands. J Pharmacol Exp Ther 290:753-760

25. Itkonen O, Koivunen E, Hurme M, Alfthan H, Schroder T, Stenman UH 1990 Time-resolved immunofluorometric assays for trypsinogen-1 and 2 in serum reveal preferential elevation of trypsinogen-2 in pancreatitis. J Lab Clin Med 115:712-718

26. Toti P, Buonocore G, Tanganelli P, Catella AM, Palmeri ML, Vatti R, Seemayer TA 1997 Bronchopulmonary dysplasia of the premature baby: an immunohistochemical study. Pediatr Pulmonol 24:22-28

27. Miotto D, Hollenberg MD, Bunnett NW, Papi A, Braccioni F, Boschetto P, Rea F, Zuin A, Geppetti P, Saetta M, Maestrelli P, Fabbri LM, Mapp CE 2002 Expression of protease activated receptor-2 (PAR-2) in central airways of smokers and nonsmokers. Thorax 57:146-151

28. Nystedt S, Ramakrishnan V, Sundelin J 1996 The proteinase-activated receptor 2 is induced by inflammatory mediators in human endothelial cells. Comparison with the thrombin receptor. J Biol Chem 271:14910-14915

29. Kotecha S, Wilson L, Wangoo A, Silverman M, Shaw RJ 1996 Increase in interleukin (IL)-1 beta and IL-6 in bronchoalveolar lavage fluid obtained from infants with chronic lung disease of prematurity. Pediatr Res 40:250-256

30. Cederqvist K, Sorsa T, Tervahartiala T, Maisi P, Reunanen K, Lassus P, Andersson S 2001 Matrix metalloproteinases-2, -8 , and -9 and TIMP-2 in tracheal aspirates from preterm infants with respiratory distress. Pediatrics 108:686-692

31. Schmidt B, Cao L, Mackensen-Haen S, Kendziorra H, Klingel K, Speer CP 2001 Chorioamnionitis and inflammation of the fetal lung. Am J Obstet Gynecol 185:173177

32. LoMonaco MB, Barber CM, Sinkin RA 1996 Differential cytokine mRNA expression by neonatal pulmonary cells. Pediatr Res 39:248-252

33. Cocks TM, Moffatt JD 2001 Protease-activated receptor-2 (PAR2) in the airways. Pulm Pharmacol Ther 14:183-191

34. Alm AK, Gagnemo-Persson R, Sorsa T, Sundelin J 2000 Extrapancreatic trypsin-2 cleaves proteinase-activated receptor-2. Biochem Biophys Res Commun 275:77-83

35. Merritt TA, Stuard ID, Puccia J, Edwards DK, Finkelstein J, Shapiro DL 1986 Newborn tracheal aspirate cytology: classification during respiratory distress syndrome and bronchopulmonary dysplasia. J Pediatr 98:949-956

36. Stiskal JA, Dunn MS, Shennan AT, O'Brien KK, Kelly EN, Koppel RI, Cox DW, Ito S, Chappel SL, Rabinovitch M 1998 alpha1-Proteinase inhibitor therapy for the prevention of chronic lung disease of prematurity: a randomized, controlled trial. Pediatrics 101:89-94

37. Hartwig W, Werner J, Jimenez RE, Z'graggen K, Weimann J, Lewandrowski KB, Warshaw AL, Fernandez-del Castillo C 1999 Trypsin and activation of circulating trypsinogen contribute to pancreatitis-associated lung injury. Am J Physiol 277:G1008-G1016

38. Pache JC, Christakos PG, Gannon DE, Mitchell JJ, Low RB, Leslie KO 1998 Myofibroblasts in diffuse alveolar damage of the lung. Mod Pathol 11:1064-1070 